UDC 338.45:338.24

JEL classification: E 61, L50, O14

Skorobogatova N. Ye.

Candidate of Economic Sciences, Associate Professor

ORCID ID: 0000-0002-2741-7629

Kravchuk Y. H.

ORCID ID: 0000-0001-8073-0414

National Technical University of Ukraine «Igor Sikorsky Kyiv Polytechnic Institute»

\title{
INFLUENCE OF INDUSTRY 4.0 ON THE COMPETITIVENESS OF THE NATIONAL ECONOMY
}

\section{ВПЛИВ ІНДУСТРІЇ 4.0 НА КОНКУРЕНТОСПРОМОЖНІСТЬ НАЦІОНАЛЬНОЇ ЕКОНОМІКИ}

The article examines the impact of Industry 4.0 on the competitiveness of the national economy. The authors identified the features of Industry 4.0 and the consequences of the production of its technologies by economic entities. The sphere of influence and global application are the main differences. The main opportunities and risks for the national economy associated with the introduction of technology Industry 4.0 are determined. In particular, the main opportunities are the development of industry, the activation and simplification of the relationship, the spread of cooperation, increasing the competitiveness of production and countries, improving the environmental friendliness of production. The main threats and risks are the increase in unemployment, political and economic instability, legislative risk, as well as the excessive growth of costs for the development and implementation of the latest technologies that may exacerbate countries' dependence on financial donors. For the purpose of thorough analysis, countries, that were selected, are divided into four groups depending on their degree of readiness to introduce the new technologies: leading countries (China, USA, Germany, France, Japan and South Korea); countries that are ready to introduce new technologies (India and Russia); countries with high potential (Australia and Ukraine); countries where the transition is just beginning (Brazil, South Africa and Saudi Arabia). The features of the implementation of the main provisions of the concept of Industry 4.0 in these groups of countries and their impact on the competitiveness of national economies are determined. The factor analysis showed a significant degree of influence of foreign direct investment, the amount of funding for research, development and other factors of innovative development on the volume of gross domestic product produced by the analyzed groups of countries. The main barriers to the implementation of Industry 4.0 technologies in national production such as the insufficient funding, lack of involvement of small and medium-sized businesses, lack of appropriate capacities and skilled labor, government strategies were identified. These barriers are inherent mainly for the countries of the fourth group. To increase the efficiency of introducing Industry 4.0 technologies, were determined the driving forces, taking into account the specifics of the economic 
development of each of the groups of the analyzed countries. Implementation of a number of measures on the basis of identifying obstacles to the use of innovative technologies in the national economy of Ukraine are proposed, in particular: enhancing the interaction of stakeholders and the state, developing the latest programs, initiatives and development strategies; increased government funding for the IT sector; deepening integration into existing EU innovation development programs; reforming the mechanism for protecting intellectual property rights in Ukraine; digitalization of basic sectors of industry and infrastructure, and more.

Keywords: Fourth Industrial Revolution, Industry 4.0, new technology, competitiveness of the national economy, risks, innovative development.

У статті досліджується вплив Індустрії 4.0 на конкурентоспроможність національної економіки. Авторами було визначено особливості Індустрії 4.0 ma наслідки провадження ї̈ технологій економічними суб'єктами. Головними відмінностями визначено сферу впливу та глобальність застосування. Визначено основні можливості та ризики для національної економіки, щзо пов'язані $з$ впровадженням технологій Індустрії 4.0. Зокрема, основними можливостями $\epsilon$ розвиток промисловості, активізачія та спрощення взаємозв'язку, поширення кооперачї, підвищення рівня конкурентоспроможності виробництва та країн, покращення екологічності виробництва. Основними загрозами та ризиками визначено підвищення рівня безробіття, політичної та економічної нестабільності, законодавчий ризик, а також непомірне зростання витрат на розробку та впровадження новітніх технологій, щчо може поглиблювати залежність країн від фінансових донорів. 3 метою грунтовного аналізу обрано краӥни, які поділено на чотири групи, залежно від ступеня їх готовності до впровадження новітніх технологій: провідні країни (Китай, США, Німеччина, Франиія, Японія та Південна Корея); краӥни, які готові до впровадження нових технологій (Індія та Росія); краӥни з високим потенціалом (Австралія та Украӥна); країни, де перехід лише починається (Бразилія, Південна Африка та Саудівська Аравія). Визначено особливості реалізації основних положень концепиії Індустрії 4.0 в зазначених групах країн та їх вплив на конкурентоспроможність національних економік. Факторний аналіз довів значний ступінь впливу прямих іноземних інвестицій, обсягів фінансування науково-дослідних робіт та інших чинників інновачійного розвитку на обсяги валового внутрішнього продукту, виробленого аналізованими групами країн. Визначено бар'єри щэодо впровадження технологій Індустрії 4.0 у національне виробництво: недостатнє фінансування, відсутність залученості малого та середнього бізнесу, відсутність відповідних потужностей та кваліфікованої робочої сили, держсавних стратегій. Зазначені бар'єри є притаманними в основному для краӥн четвертої групи. Задля підвищення ефективності впровадження технологій Індустрії 4.0 визначено рушійні сили 3 врахуванням особливостей економічного розвитку кожної з груп досліджуваних краӥн. На основі виявлення перешкод щуодо використання інновачійних технологій у начіональну економіку України запропоновано реалізацію низки заходів, зокрема: активізація взаємодії стейкхолдерів та держави, розробка новітніх програм, ініиіатив та стратегій розвитку; збільшення обсягів фінансування IT-сектору 3 боку держави; поглиблення інтеграџії до існуючих програм інноваційного розвитку ЄС; реформування механізму захисту прав інтелектуальної власності в Україні; діджиталізачія базових секторів промисловості та інфраструктури, тощо. 
Ключові слова: Четверта промислова революція, Індустрія 4.0, новітні технології, конкурентоспроможність національної економіки, ризики, інноваційний розвиток.

Introduction. Today, the world is undergoing a transition from the stage of initial automation of processes and the spread of automated electronics, were formed during the Third Industrial Revolution, to the development of a full-fledged ecosystem, characterized by a change in the human worldview at a deep, namely, "molecular" level. Currently, the key role is given to information, human knowledge and technology. It is the technologies that are now at the level of origin and formation that have the ability to independently acquire, through messages, the exchange of data and information, knowledge. Exactly technologies that are at the level of origin and formation now, have the ability to independently acquire, through messages, the exchange of data and information, knowledge.

Many domestic and foreign scientists were engaged the impact of Industry 4.0 on the competitiveness of the national economy. H. Kagermann, V. D. Lucas, V. Walter [1], M. Ryusman, M. Lorenz, F. Herbert, M. Waldner, J. Yustus, P. Engel, M. Harnish [2] and other scientists were engaged theoretical and methodological issues. The works of V.V. Vitlinsky, V.I. Skitsko [3], V.I. Khakhanov [4] and others should be highlighted regarding the identification and risk assessment of the implementation of the concept of Industry 4.0. At the same time, the problem of a comprehensive assessment of the impact of Industry 4.0 technologies on the formation and support of national economies of various groups of countries remains unstudied.

The purpose of the study. The aim of the study is to improve the scientific and methodological foundations and develop practical recommendations for ensuring the competitiveness of the national economy in the conditions of Industry 4.0. To achieve this goal were set and solved the following tasks: study the features of Industry 4.0 and its consequences on the national economy; carry out factor analysis of the impact of Industry 4.0 on the competitiveness of the national economy; determine the prospects for the development of the competitiveness of the economies of various countries through the widespread use of Industry 4.0 technologies.

Methodology. The theoretical and methodological basis of the research is the scientific works of leading domestic and foreign scientists in the field of Industry 4.0 and its impact on competitiveness, analytical reports of leading companies in the world on assessing the degree of influence of Industry 4.0 on the competitiveness of national economies. The solution of the tasks was carried out using the following research methods: methods of generalization and systematization in the study of the essence of the concept «Industry 4.0»; grouping methods, graphical, statistical methods when 
analyzing the level of influence of Industry 4.0 on the competitiveness of national economies; methods of analysis and synthesis, economic and statistical methods in determining measures to increase the level of the competitiveness of countries in the conditions of Industry 4.0.

Research results. Modern historical and economic science distinguishes four large qualitative leaps in the history of mankind - four revolutions in the productive forces of society and in the structures of society itself (Table 1). The current era of innovation is called "Industry 4.0". It is characterized by the fact that advanced technologies are radically changing entire sectors of the economy at an amazingly fast pace. There is also a completely new type of industrial production, which will be based on the Big Data and its analysis, full automation of production, augmented reality (AR) technologies, the Internet of Things (IoT), and other.

Table 1 - The periods of industrial revolutions and their main characteristic

\begin{tabular}{|c|c|c|c|c|}
\hline \multirow[b]{2}{*}{$\begin{array}{c}\text { Elements of } \\
\text { technical } \\
\text { progress }\end{array}$} & \multicolumn{4}{|c|}{ Periods of highest concentration of qualitative shifts } \\
\hline & $\begin{array}{l}\text { The end of } \\
\text { the XVI - } \\
\text { beginning of } \\
\text { the XIX } \\
\text { century. } \\
\text { (First } \\
\text { Industrial } \\
\text { Revolution) }\end{array}$ & $\begin{array}{l}\text { The last third of } \\
\text { the XVI - the } \\
\text { beginning of the } \\
\text { XX century. } \\
\text { (Second } \\
\text { Industrial } \\
\text { Revolution) }\end{array}$ & $\begin{array}{l}\text { The middle of } \\
\text { the XX - the } \\
\text { beginning of the } \\
\text { XXI century. } \\
\text { (Third Industrial } \\
\text { Revolution) }\end{array}$ & $\begin{array}{c}2011 \text { - to this } \\
\text { day } \\
\text { (Fourth } \\
\text { Industrial } \\
\text { Revolution) }\end{array}$ \\
\hline $\begin{array}{c}\text { Tools and } \\
\text { means of labor }\end{array}$ & $\begin{array}{l}\text { The } \\
\text { emergence } \\
\text { of machine } \\
\text { production }\end{array}$ & $\begin{array}{l}\text { Coverage of basic } \\
\text { work processes } \\
\text { by machine } \\
\text { production; mass } \\
\text { production of } \\
\text { machines }\end{array}$ & $\begin{array}{l}\text { Formation of } \\
\text { machine } \\
\text { systems, } \\
\text { complex } \\
\text { mechanization, } \\
\text { production } \\
\text { automation }\end{array}$ & $\begin{array}{l}\text { Production } \\
\text { automation, } \\
\text { cyberphysical } \\
\text { systems in } \\
\text { production, } \\
\text { Internet of } \\
\text { Things }\end{array}$ \\
\hline Driving force & $\begin{array}{l}\text { Steam } \\
\text { engine }\end{array}$ & $\begin{array}{l}\text { Electricity } \\
\text { generation, } \\
\text { electric motor, } \\
\text { internal } \\
\text { combustion } \\
\text { engine }\end{array}$ & $\begin{array}{l}\text { Electrification of } \\
\text { production, } \\
\text { nuclear reactor, } \\
\text { jet engine }\end{array}$ & $\begin{array}{c}\text { Cyberphysical } \\
\text { systems, } \\
\text { Internet of } \\
\text { Things, Big } \\
\text { Data, cloud } \\
\text { computing, } \\
\text { artificial } \\
\text { intelligence, } \\
\text { etc. } \\
\end{array}$ \\
\hline $\begin{array}{c}\text { Means of } \\
\text { communication }\end{array}$ & $\begin{array}{l}\text { Postal } \\
\text { service }\end{array}$ & $\begin{array}{c}\text { Electrical } \\
\text { communications } \\
\text { (telegraph, } \\
\text { telephone) }\end{array}$ & $\begin{array}{l}\text { Radio } \\
\text { communication } \\
\text { and electronics }\end{array}$ & Internet \\
\hline
\end{tabular}

Source: compiled by the authors by source [5] 
Despite the identification by some scientists [6-10] of the concepts of the Fourth Industrial Revolution and Industry 4.0, they have a number of differences. In particular, experts of the Association of Industrial Automation Enterprises of Ukraine [11] note that the main differences are that Industry 4.0 emerged as a state initiative, first applied by Germany and its sphere of influence is much narrower - only industry. However, it is a number of similarities, such as the use of the same technologies (Internet of things, artificial intelligence, cloud technologies, etc.) and the growing role of innovation.

The concept of Industry 4.0 is based on four principles: the interoperability of man and machine, namely the ability to contact directly via the Internet; transparency of information and the ability of systems to create a virtual copy of the physical world; technical assistance of machines to humans - combining large amounts of data and performing a number of tasks which are dangerous to humans; the ability of systems to make decisions independently and autonomously [12]. The analysis of scientific works and analytical information made it possible to systematize the main opportunities and risks for the national economy, causing the introduction of Industry 4.0 technologies (Table 2 ).

Table 2 - Opportunities and risks for national economies in introducing Industry 4.0

\begin{tabular}{|c|l|c|l|}
\hline Opportunity & \multicolumn{1}{|c|}{ Characteristic } & Risk & \multicolumn{1}{c|}{ Characteristic } \\
\hline $\begin{array}{c}\text { Industry } \\
\text { development }\end{array}$ & $\begin{array}{l}\text { Improving the efficiency of } \\
\text { enterprises by introducing new } \\
\text { technology }\end{array}$ & Unemployment & $\begin{array}{l}\text { Replacing a large number of } \\
\text { professions with robots }\end{array}$ \\
\hline Relationship & $\begin{array}{l}\text { The Internet of Things will } \\
\text { develop communication between } \\
\text { government, government } \\
\text { agencies, businesses and } \\
\text { consumers }\end{array}$ & Instability & $\begin{array}{l}\text { Increasing the level of political } \\
\text { and economic instability }\end{array}$ \\
\hline Cooperation & $\begin{array}{l}\text { Involvement of less developed } \\
\text { countries by leading countries in } \\
\text { the implementation of projects } \\
\text { related to the development of } \\
\text { Industry 4.0 }\end{array}$ & Legislative & $\begin{array}{l}\text { Adoption of an unreasonable } \\
\text { development strategy for the } \\
\text { concept of Industry 4.0 due to } \\
\text { inconsistent views of various } \\
\text { participants }\end{array}$ \\
\hline $\begin{array}{c}\text { Competitiveness } \\
\text { increasing the country's position } \\
\text { in the international arena of } \\
\text { competitiveness }\end{array}$ & Excessive costs & $\begin{array}{l}\text { The introduction of new } \\
\text { technologies entails significant } \\
\text { costs for which most countries are } \\
\text { not ready }\end{array}$ \\
\hline $\begin{array}{c}\text { Environmental } \\
\text { friendliness }\end{array}$ & $\begin{array}{l}\text { Reducing the volume of "dirty" } \\
\text { production }\end{array}$ & $\begin{array}{l}\text { Deepening the dependence of } \\
\text { developing countries on leading } \\
\text { (economically developed) } \\
\text { countries }\end{array}$ \\
\hline
\end{tabular}

Source: compiled by the authors by source [13 - 15] 
However, the opinion of all scientists in this context is the same Industry 4.0 plays an important role in the global economy. According to the World Bank [16], annual global production exceeds \$ 11 trillion. As estimated by McKinsey [17], the introduction of Industry 4.0 elements allows both reducing costs and increasing sales. The use of new technologies due to an increase in labor productivity by $45-55 \%$ simultaneously reduces equipment maintenance costs by $10-40 \%$ and equipment downtime by 30 $50 \%$, improves quality indicators by $10-20 \%$ and reduces storage costs by $20-50 \%$. The term for launching new products on the market is reduced by $20-50 \%$, the accuracy of sales forecasting is increased to the level of $85 \%$ and higher [17]. The leaders in the implementation of technologies for Industry 4.0 are a number of innovatively active countries that occupy leading positions in international rankings.

The leader in production of robots is China. In 2014, the President of China Xi Jinping made a speech at the Chinese Academy of Sciences about the upcoming robot revolution, which will transform China and then the whole world. The Chinese government has set the country the task of accelerating the introduction of Big Data, Cloud Computing, and the Internet of Things into Chinese companies and focus on creating "Intelligent Manufacturing" [18].

In recent years, Chinese companies have increased investment in hightech developments around the world and, as a result, according to the International Federation of Robotics (IFR) [19], starting in 2013, the Chinese market of industrial robots has become the largest in the world. At the same time, there are already 150 robots per 10000 industrial workplaces by the beginning of 2020 in China, which is three times more than in 2015. Developed countries such as the US and Germany are finding it increasingly difficult to overtake China. So, in the USA in 2014 a non-profit consortium of the Industrial Internet was created [20], while Japan defines its own concepts of Connected Factories (connecting to the network of factories) for the development of its own industry [21]. A graphical representation of the dynamics of the supply of industrial robots in the world is shown in Fig. 1.

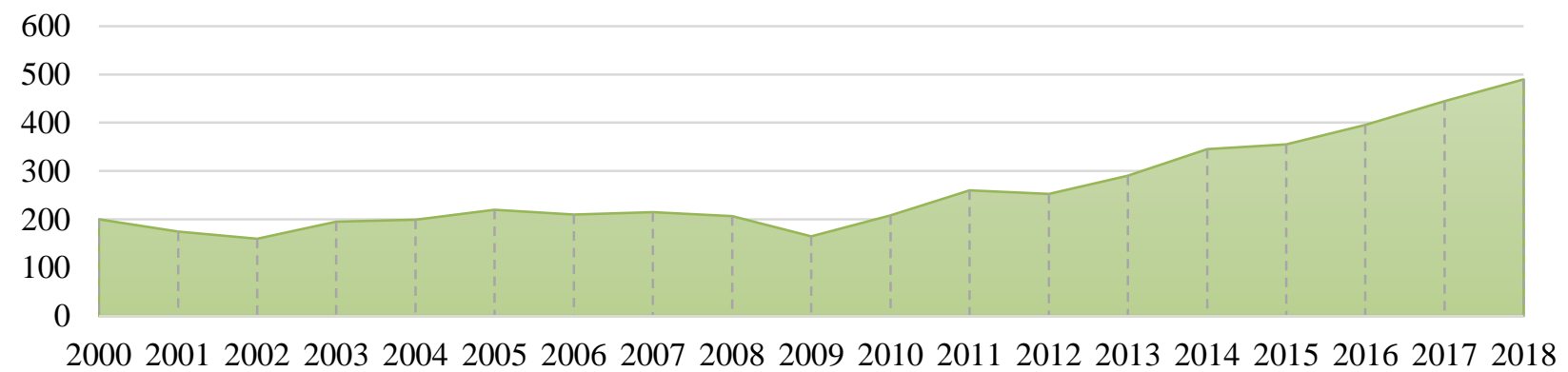

Figure 1 - The dynamics of the supply of industrial robots in the world, thousand units

Source: built by the authors according to [19] 
At the same time, as estimated by experts of the International Federation of Robotics [19], a breakthrough in technology is expected in the interaction between man and machine. McKinsey estimates that by 2025 cyber-physical systems will be able to fulfill $15-25 \%$ of the functions of workers in developed countries and 5-15\% in developing countries.

To study the impact of Industry 4.0 on the competitiveness of the national economy, according to the results of the rating of the project "Readiness of countries for the production of the future" [1], selected countries were divided into four groups: Korea);

- leading countries (China, USA, Germany, France, Japan and South

- countries, that are ready for the introduction of new technologies (India and Russia);

- countries with high potential (Australia and Ukraine);

- countries where the transition is just beginning (Brazil, South Africa and Saudi Arabia).

The United States is the leader in the technologies of Internet of Things (GE, Intel), cybersecurity (Symantec, IBM, Intel), augmented and virtual reality systems (Facebook, AMD, Google, Microsoft). Japan occupies a leading position in the market of robots and machines with numerical program control. Germany is also a leader in a number of areas [19].

China leads in the number of patents in the field of artificial intelligence, accounting for $53 \%$ of all patents in this field, the second position is occupied by the United States $-27 \%$ and the third by Japan $-6 \%$, while Ukraine has a share of less than $1 \%$ [1]. At the same time, India and Russia have a strong base for the introduction of the latest technologies in Industry 4.0, but do not have an active policy to disseminate this concept. This has led to the fact that their pace of development is much lower than in previous countries. At the same time, it should be noted that the implementation of Industry 4.0 technologies requires significant costs, which often hinders their large-scale implementation.

Ukraine and other countries in the group are less ready to implement Industry 4.0 technologies. In particular, experts note that they need to improve the situation regarding Industry 4.0 drivers. The main problems of these countries are technological backwardness from the world's leading countries, as well as the lack of adequate funding in this area.

As for the countries of the African continent, they should maximize the development of technologies of Industry 4.0 and use them to find solutions to their numerous problems. Enhancing the implementation of technologies of Industry 4.0 in the continent, which has 54 countries, is much more challenging than in one, even a large country. The solution to this issue is complicated by the fact that all these countries are at different 
stages of development. We believe that, first of all, the countries of this continent require a global rethinking and leaders who understand that the future lies with technology [22].

Analysis of statistical and analytical data has proved the need for significant investment resources for the introduction of the latest technologies, which, in its turn, will contribute to GDP growth. In particular, the net inflow of foreign direct investment has a direct impact on the country's nominal GDP (correlation coefficient is 0.892). Between these indicators is a parabolic relationship.

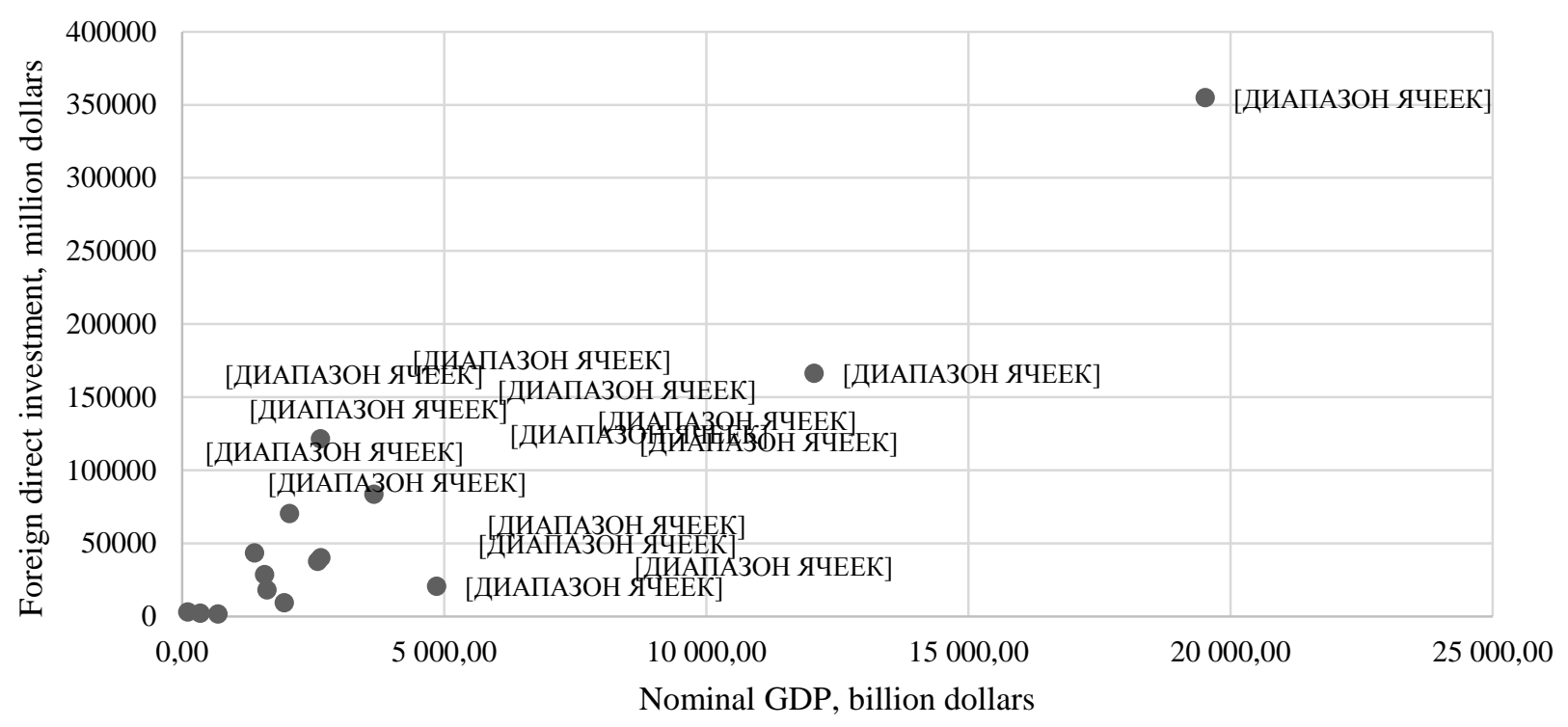

Figure 2 - Dependence of nominal GDP on FDI

Source: created by the authors according to [23]

Among the countries selected for analysis, the USA has the largest net FDI inflow (35648 million dollars) and, accordingly, the largest volume of nominal GDP (19519,4 billion dollars). Saudi Arabia and Ukraine have the lowest net FDI inflows, which in turn affects GDP. The analysis of statistical data also shows a close relationship between GDP and R\&D expenditures (Fig. 3). The identified dependencies prove the need for active $R \& D$ funding, which will have influence on the growth of the country's GDP and its level of competitiveness. At the same time, GDP growth allows allocating a larger share of it to R\&D financing to ensure the country's competitiveness. The research revealed the ambiguity of this dependence for certain countries. In particular, South Korea has the largest share of R\&D in GDP, but nominal GDP is an inappropriate value of GDP among the countries under consideration. At the same time, the opposite situation is observed in China and the United States. They have the largest nominal GDP among the represented countries, but the share of R\&D in GDP is much smaller than in 
South Korea. This situation is explained by the scale of production and the structure of GDP of these countries.

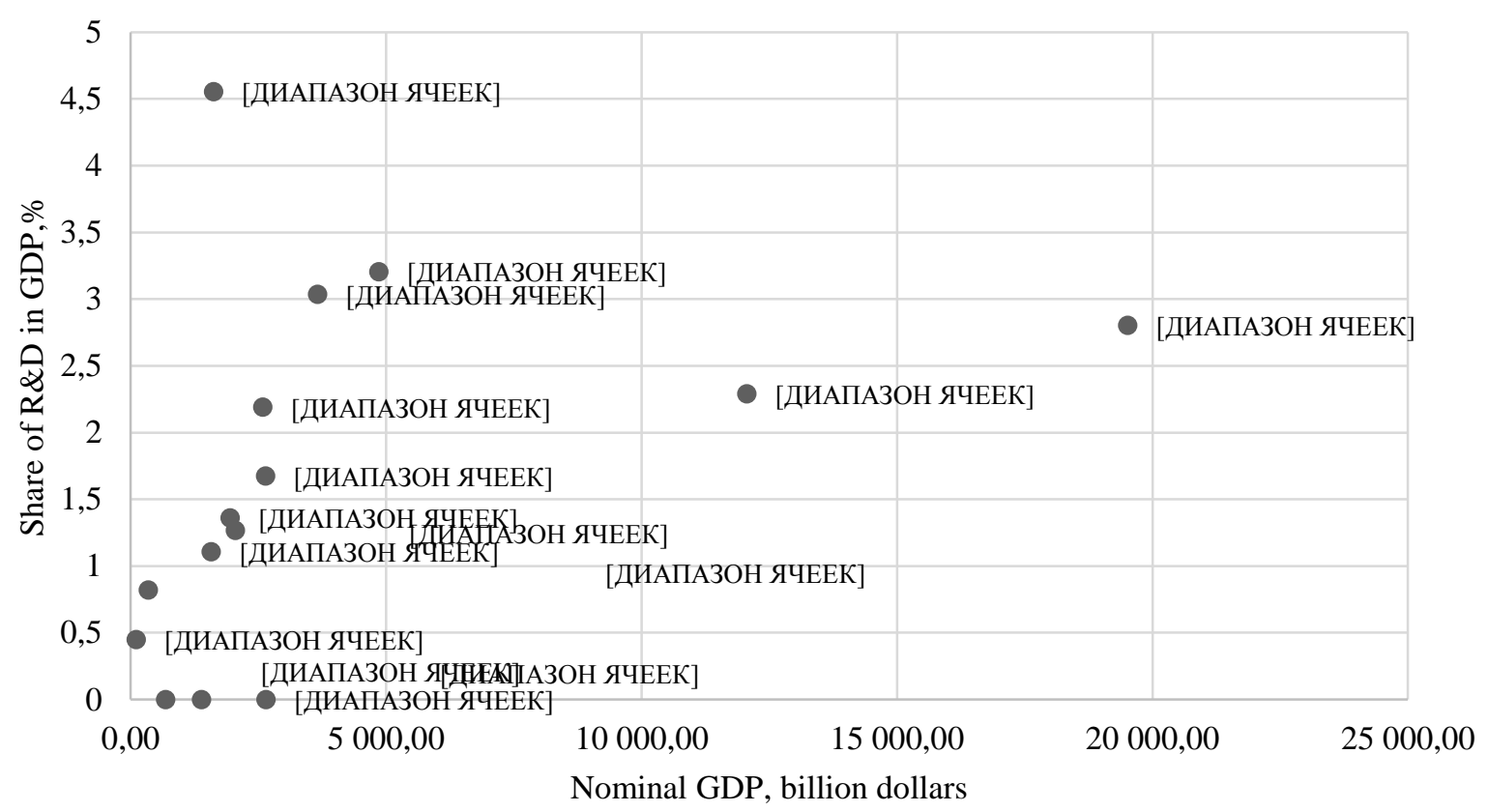

Figure 3 - Dependence of nominal GDP on the share of R\&D Source: created by the authors according to [23]

The analysis of sources of financing $R \& D$ expenditures shows their diversity: own funds of business, state support and attraction of foreign investments (Fig. 4). At the same time, intellectual property is the result of $\mathrm{R} \& \mathrm{D}$, directly affecting the country's economic development and its competitiveness.

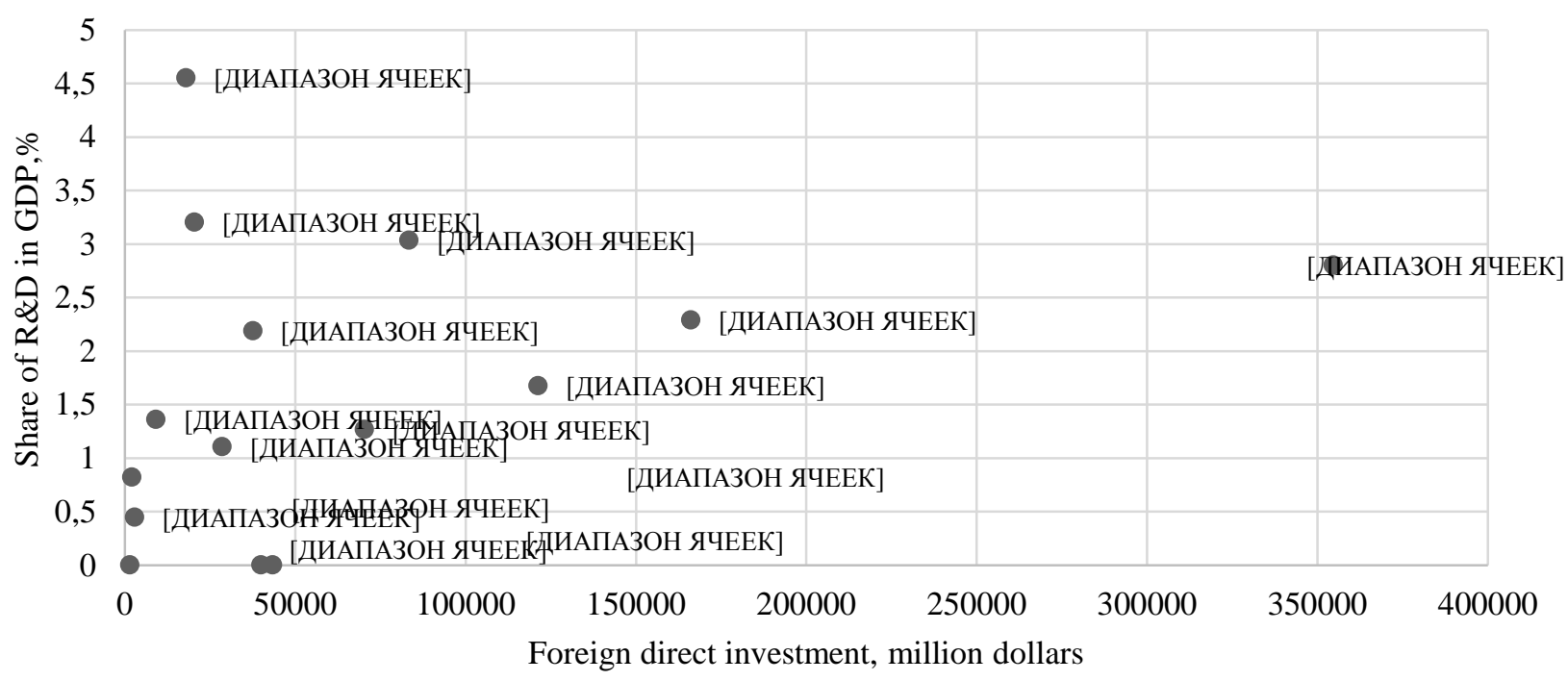

Figure 4 - Dependence of the share of R\&D on FDI

Source: created by the authors according to [23] 
However, it should be noted that not all countries have the same trends. In particular, China has the largest number of patents, but the share of $\mathrm{R} \& \mathrm{D}$ in GDP is much lower than, for example, in South Korea, which is significantly inferior to the number of patents in China. At the same time, we think that only the leading countries of the world will achieve significant success. For the second group of countries the impact will be much smaller, because they have a basis for development, but do not fully develop this area. In particular, only $10 \%$ of enterprises in the second group of countries have developed strategies for the implementation of Industry 4.0, among them $90 \%$ of enterprises have received a profit growth of 5\% [1]. As estimated by McKinsey experts [17], the countries of the second group can get a GDP growth of $19-34 \%$ by 2025 , the industrial sector is able to increase GDP by $5-18 \%$. In order to increase the effect of introducing Industry 4.0 technologies, we consider it necessary to carry out a number of measures to stimulate the development of this area: increasing the level of interconnection between government, business and universities; improving the investment climate of the country; identification of advanced industries for the priority implementation of Industry 4.0, etc.

To increase the efficiency of introducing Industry 4.0 technologies, it is necessary to implement a number of preparatory actions, at best, estimated by experts [17], it will allow you to get $+11 \%$ to GDP and labor productivity by about $1,5 \%$. At the same time, this will lead to an increase in the industrial sector by $7 \%$, and the development of high-tech production will increase by $15-20 \%$, increasing the efficiency of enterprise equipment to $15 \%$. However, there are a number of barriers that countries need to overcome, namely, imperfect legal framework, lack of state support and others.

The prospects for the development of Industry 4.0 for the countries of the fourth group are not clearly defined. We think it is necessary to balance macroeconomic indicators and address the political situation to intensify the introduction of Industry 4.0 technologies in the countries of this group. The introduction of new technologies entails significant costs that the countries of this group cannot afford, so they need to seek additional funding among the world's leading countries. At the same time, it should be noted that this way of finding funding sources carries the danger of becoming dependent on them.

In general, it should be noted that the development of Industry 4.0 technologies has significant potential, both for individual countries and for the global economy as a whole. According to the forecast values shown in Fig. 5, in 2022 the market of artificial intelligence will bring countries of the world 13.3 billion dollars. 


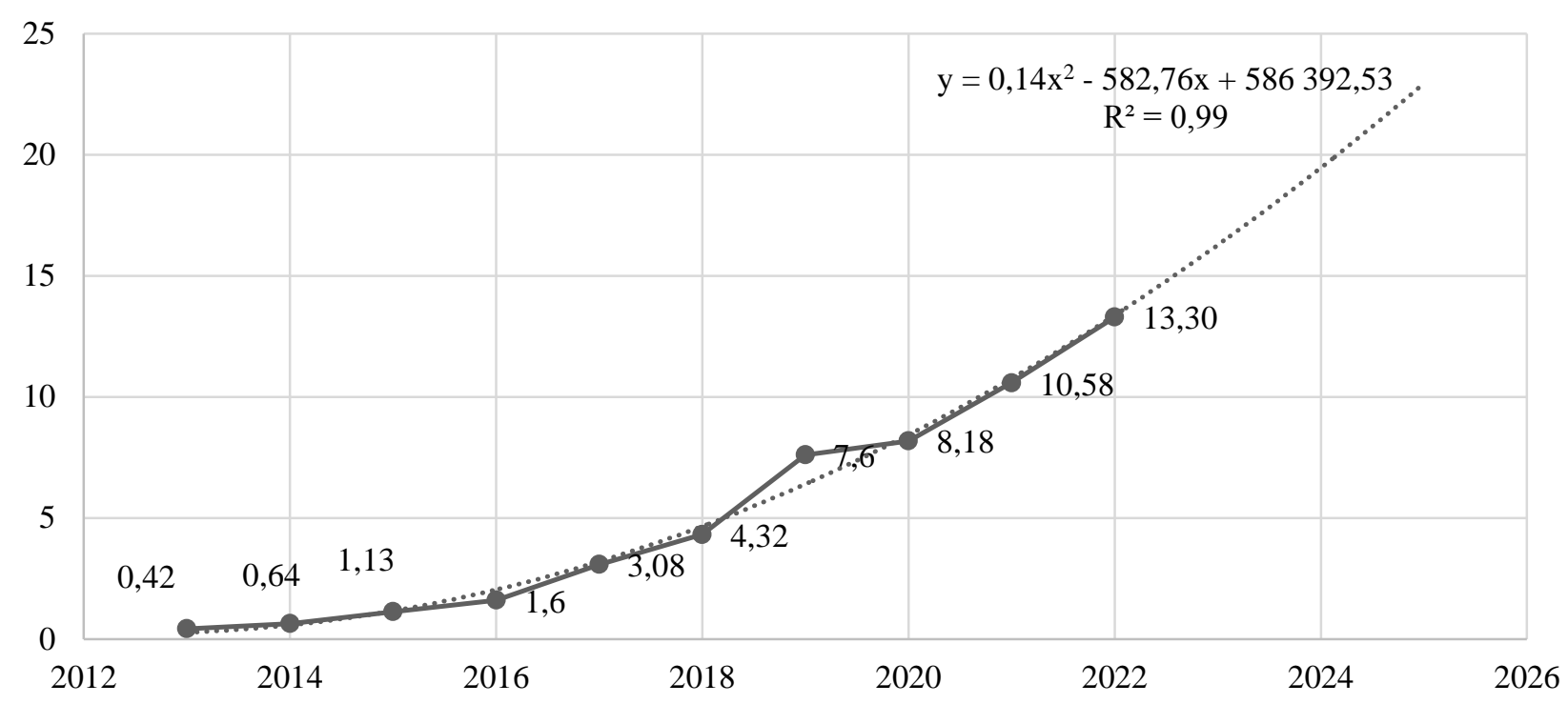

Figure 5 - Forecast of the development of the artificial intelligence market in the world, billion dollars

Source: created by authors according to [89]

Technology such as the Internet of Things will also bring significant economic value. The research of various segments has shown that the Internet of Things will have a massive impact on countries around the world, in particular, the greatest value will be for industry - 3700 billion dollars. until 2025 (Fig. 6).

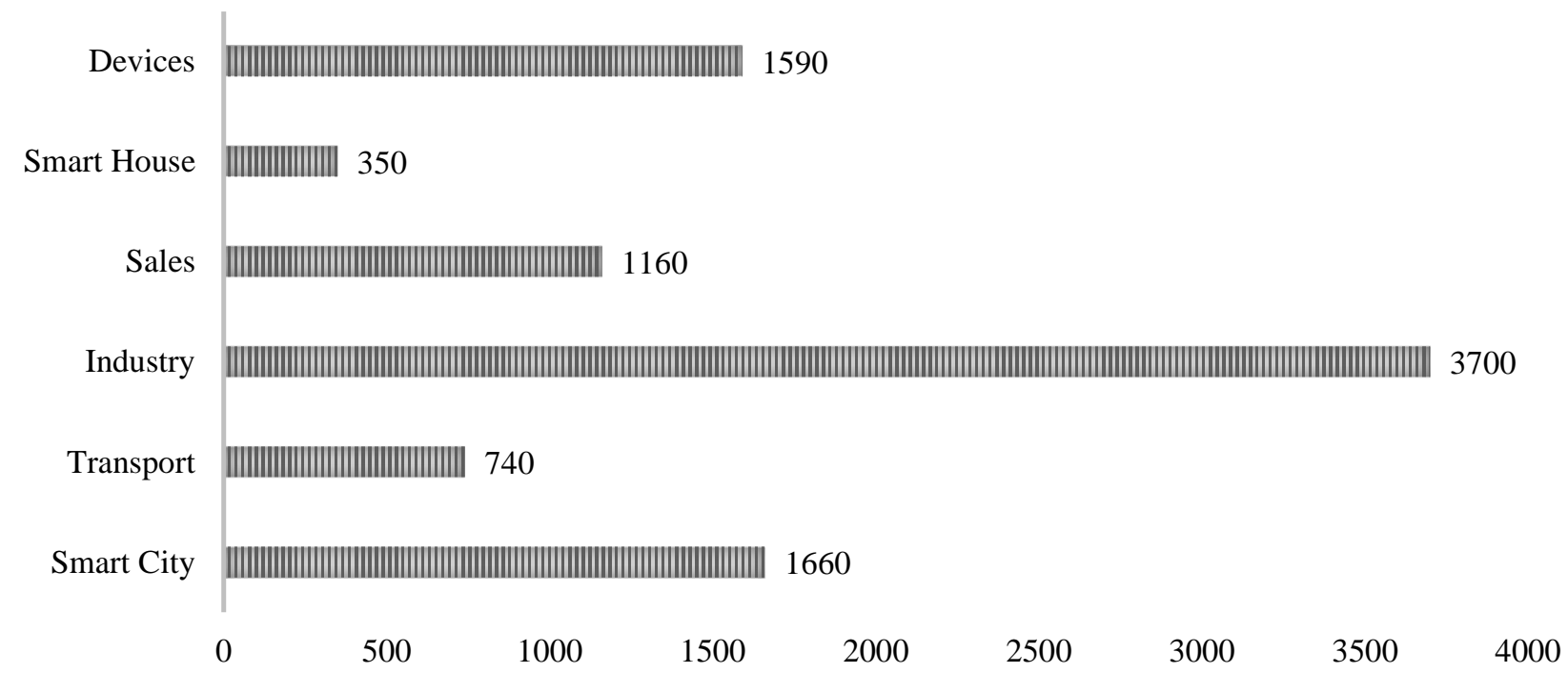

Figure 6 - Forecast on the economic value created by the Internet of Things in the world by 2025 , billion dollars Source: created by authors according to [90]

The research identified the driving forces of Industry 4.0 for four groups of countries. Table 3 shows that the most promising are the countries of the first group, and the least developed in terms of factors of development 
of Industry 4.0 are the countries of the fourth group. At the same time, it is determined that the main barriers to the implementation of Industry 4.0 are the following: insufficient funding, lack of involvement of small and medium-sized businesses, lack of adequate capacity and skilled labor, government strategies. These barriers are inherent mainly for the countries of the fourth group.

Table 3 - Driving forces of Industry 4.0 in the analyzed countries

\begin{tabular}{|c|c|c|c|c|c|c|}
\hline \multirow[b]{2}{*}{ No } & \multirow[b]{2}{*}{ Country } & \multicolumn{5}{|c|}{ Driving forces of Industry 4.0} \\
\hline & & $\begin{array}{l}\text { Sectoral } \\
\text { environment/ } \\
\text { demand }\end{array}$ & $\begin{array}{l}\text { International } \\
\text { cooperation }\end{array}$ & $\begin{array}{c}\text { Regional } \\
\text { authorities }\end{array}$ & Public funding & $\begin{array}{c}\text { State } \\
\text { initiatives }\end{array}$ \\
\hline \multicolumn{7}{|c|}{ I group } \\
\hline 1 & France & & & & & \\
\hline 2 & United Kingdom & & & & & \\
\hline 3 & China & & & & & \\
\hline 4 & Germany & & & & & \\
\hline 5 & South Korea & & & & & \\
\hline 6 & Japan & & & & & \\
\hline 7 & USA & & & & & \\
\hline \multicolumn{7}{|c|}{ II group } \\
\hline 8 & Russia & & & & & \\
\hline 9 & India & & & & & \\
\hline \multicolumn{7}{|c|}{ III group } \\
\hline 10 & Ukraine & & & & & \\
\hline 11 & Australia & & & & & \\
\hline \multicolumn{7}{|c|}{ IV group } \\
\hline 12 & Saudi Arabia & & & & & \\
\hline 13 & Brazil & & & & & \\
\hline 14 & South Africa & & & & & \\
\hline
\end{tabular}

Source: created by the authors

The research suggests that the introduction of Industry 4.0 technologies will have a clear positive effect on business processes, in particular: increasing sales, optimizing production processes, diversifying goods and services, the emergence of new business models, improving service and other. At the same time, it should be noted that such successes will be achieved only by the countries of the first group, while the others will have a partial effect.

The analysis of the practice of implementing Industry 4.0 technologies in Ukraine allowed determining the presence of the following problems: lack of an approved state strategy for the development priorities of Industry 4.0 in 
Ukraine; reduction of funding for research activities in Ukraine and the number of domestic researchers; legislative problems on the protection of intellectual property rights; unstable economic and political situation in the country; essential financial costs, which are associated with the implementation and use of Industry 4.0 technologies, cannot be afforded by most Ukrainian enterprises.

In order to ensure the competitiveness of the national economy of Ukraine in the conditions of Industry 4.0 , it is proposed to implement a number of measures, namely: increasing the level of interaction between existing stakeholders and the state, creating new programs, initiatives, development strategies; expanding funding for the IT sector; deepening integration into existing EU programs; reforming the procedure for protection of intellectual property rights; digitalization of basic sectors of industry and infrastructure, etc. [24]. We think that the implementation of the proposed measures will increase the competitiveness of the national economy of Ukraine in the context of the spread of Industry 4.0.

Conclusions. The results of the study suggest that the introduction of Industry 4.0 technologies leads to many positive consequences of both technological and economic nature. The research of four groups of countries depending on the degree of their readiness to implement the technologies of Industry 4.0 (leading countries; countries, that are ready for the introduction of new technologies; countries with high potential; countries where the transition is just beginning) showed the following results. Leading countries (first group), using the methods and tools of Industry 4.0, have improved financial indicators, such as reducing costs and increasing investment in science-intensive, most importantly, it helps to increase the country's competitiveness at the global level. Other countries had correspondingly lower results from the introduction of Industry 4.0 technologies.

The research proved that to form the competitive advantages of the economy, countries, it needs to implement the tools of Industry 4.0, take into account factors of competitiveness and spread the goals and principles of sustainable development: pay attention to increasing production and exports of high technology, ICT, which, in turn, will lead to increasing of investment in the country, improving the economic situation, increasing the number of jobs, automation and robotization of production.

Elements of scientific novelty include the author's developments on the forecasts of Industry 4.0 technologies and their impact on the competitiveness of national economies, depending on the degree of their economic and innovative development. In particular, it is determined that the introduction of Industry 4.0 technologies will have a positive effect on business processes, in particular: increasing sales, optimizing production processes, diversifying goods and services, the emergence of new business 
models, improving service, etc. The greatest economic effect can be brought by technologies of artificial intelligence and the Internet of Things.

The development of a methodology for assessing the degree of impact on the economic well-being of the country is the subject of further economic research.

\section{References:}

1. Kagermann H., Anderl R., Gausemeier J., Schuh G., Wahlster W. Industrie 4.0 in a Global Context - $\quad$ Germany, $2018 . \quad$ URL: https://www.researchgate.net/publication/315739153 Industrie_40_in_a_Global_Context_Strategies_for_Cooperating_with_International_ Partners_acatech_STUDY.

2. Russmann M., Lorenz M., Gerbert P., Waldner M., Justus J., Engel P., Harnisch M. Industry 4.0: The Future of Productivity and Growth in Manufacturing Industries. URL: https://www.bcgpers/pectives.com/content/articles/engineered_products_/ project_business_industry_40_future_productivity_/growth_manufacturing_industrie s.

3. Vitlinsky V. V., Skitsko V. I. Risks in Industry 4.0. Bulletin of Cherkasy University, 2016. № 3. P. 17-26.

4. Khakhanov V. I. Smart Cyber-University - Cloud-Mobile services management of scientific and educational processes. Radioelectronics and Informatics, 2015. № 3. P. 3944.

5. Budnikov Y. I. History of science and technology: guidelines for the study of the course. Chelyabinsk: teaching materials of the Department of Domestic and Foreign History of SUSU, 2017. 42 p.

6. Voronin S. M., Morozova N. N. Improving the competitiveness of industry based on the concept of "Industry 4.0". Management Issues, 2019. № 1 (71). P. 15-20.

7. Schetinina N. Yu. Industry 4.0: practical aspects of implementation in Russian conditions. Models, systems, networks in economics, technology, nature and society, 2017. № 1 (21). P. 75-84.

8. Detter G. F. "Big Challenges" for the Development of the Arctic Spaces in the Conditions of the Fourth Industrial Revolution. Innovation, 2017. № 11 (229). P. 2228.

9. Tarasov I. V. Industry 4.0: concept, concepts, development trends. Business Strategies, 2018. № 6 (50). P. 43-49.

10. Gotz M. The potential of clusters to form demanded competencies and develop business flexibility. Forsyth, 2019. № 2. P. 72-83.

11. Official page of the Association of Industrial Automation Enterprises of Ukraine. URL: https://appau.org.ua/.

12. Fink P. Industry 4.0 and European Innovation Policy. URL: https://library.fes.de/pdffiles/wiso/14455.pdf.

13. Zubritskaya I. The concept of "Industry 4.0" and the prerequisites for its application in domestic industry. Science and Innovation, 2017. № 7 (185). P. 38-41.

14. Andryushchenko K. A., Shergina L. A., Kovtun V. P. Analysis of features and prospects for the development of Ukraine in the concept of "Industry 4.0". Technology audit and resource conservation, 2017. № 4 (5). P. 36-42. 
15. Official website of the project "Public Synergy". URL: https://www.civicsynergy.org.ua/.

16. Official website of World Bank Group. URL: https://www.worldbank.org/uk/.

17. Official website of McKinsey \& Company. URL: https://www.mckinsey.com/.

18. Kusiak A. Journal of Intelligent Manufacturing. URL: https://www.springer.com/journal/10845/.

19. Official website of International Federation of Robotics. URL: https://ifr.org/.

20. Official website of IoT Analytics. URL: https://iot-analytics.com/.

21. Official website of Production Management. URL: http://www.up-pro.ru/.

22. Official website of UNESCO. URL: https://ru.unesco.org/.

23. Official website of Knoema. URL: https://knoema.com/.

24. Skorobogatova N. Y., Kravchuk Y. H. Ukraine's readiness to introduce the latest technologies of Industry 4.0. Entrepreneurship and innovation. 2019. № 7. P. 26-32. DOI: https://doi.org/10.37320/2415-3583/7.4. 